\title{
Leaf anatomy and its contribution to the systematics of Aechmea subgenus Macrochordion (de Vriese) Baker (Bromeliaceae)
}

\author{
ANA PAULA G. DE FARIA ${ }^{1}$, ANA CLAUDIA M. VIEIRA ${ }^{2}$ and TÂNIA WENDT ${ }^{3}$ \\ ${ }^{1}$ Instituto de Ciências Biológicas, Departamento de Botânica, Universidade Federal de Juiz de Fora, \\ Campus Universitário, Bairro São Pedro, 36036-900 Juiz de Fora, MG, Brasil \\ ${ }^{2}$ Faculdade de Farmácia, Departamento de Produtos Naturais e Alimentos, Universidade Federal do Rio de Janeiro, \\ CCS, Ilha do Fundão, 21941-590 Rio de Janeiro, RJ, Brasil \\ ${ }^{3}$ Instituto de Ciências Biológicas, Departamento de Botânica, Universidade Federal do Rio de Janeiro, \\ CCS, Ilha do Fundão, 21941-590 Rio de Janeiro, RJ, Brasil
}

Manuscript received on February 7, 2011; accepted for publication on June 6, 2011

\begin{abstract}
The leaf anatomy of the species Aechmea subgenus Macrochordion was analyzed to obtain valuable data on their taxonomic delimitation and to identify anatomical adaptations to their respective habitats and habits. All leaves of these species are hypostomatic, and present: peltate trichomes on both surfaces; stomata sunk in epidermal depressions; small epidermal cells with thick walls and inclusions of silica bodies; a mechanical hypodermis; an aquiferous parenchyma; chlorenchyma with fibrous clusters and air channels; and vascular bundles surrounded by a parenchymatic sheath and a cap of fibers. The results are evaluated within an adaptive and taxonomic context. Variations in hypodermic thickening, amount of water parenchyma, position of the air channels and shape of the cells filling the air channels are useful for delimiting groups of species, strengthening the relationships suggested by their external morphology.
\end{abstract}

Key words: Aechmea, Bromeliaceae, leaf anatomy, Macrochordion.

\section{INTRODUCTION}

The Bromeliaceae includes 3,172 species (Luther 2008) and is a representative monocot family for Neotropical flora. It occupies a basal position within the Poales order and is closely related to Typhaceae and Rapateaceae (APG III 2009). Bromeliads demonstrate remarkable ecological versatility, inhabiting mesic to xeric environments (e.g. humid tropical forests to deserts) and display a wide range of terrestrial, lithophytic and epiphytic habits (Smith 1934, Benzing 2000a). Some morphological

Correspondence to: Ana Paula Gelli de Faria

E-mail: ana.gelli@ufjf.edu.br. and physiological adaptations to drier habitats and particular life forms out of the soil include the presence of a central tank (which allows the plant to collect water and organic material inside enlarged and overlapping leaf sheaths), leaves with absorbing scales (the most distinguishing feature of the family, also referred to as peltate trichomes), water storage and mechanical support tissues, the development of 'crassulacean acid metabolism' (CAM) photosynthesis, and the progressive structural and functional reduction of root systems in epiphytic and rupiculous species (Tomlinson 1969, Benzing 1976, 2000a, b). 
The Bromeliaceae is traditionally divided into the subfamilies Pitcairnioideae, Bromelioideae and Tillandsioideae(Smithand Downs 1974, 1977, 1979). A recent molecular phylogenetic study suggests that it could be divided into eight monophyletic lineages (including Bromelioideae and Tillandsioideae) due to the paraphyly of Pitcairnioideae (Givnish et al. 2007). Bromelioideae species are typically distinguished by the inferior ovary, baccate and indehiscent fruits and unappendaged seeds (Smith and Downs 1979). However, the generic delimitation of this subfamily is the less understood in Bromeliaceae, particularly within Aechmea Ruiz \& Pav., the largest (with more than 250 species; Luther 2008) and morphologically most diverse genus of Bromelioideae (Faria et al. 2004). In the last monograph on Bromelioideae, Smith and Downs (1979) recognized eight subgenera for Aechmea: Aechmea, Chevaliera (Gaudich. ex. Beer) Baker, Lamprococcus Beer (Baker), Macrochordion de Vriese (Baker), Ortgiesia (Regel) Mez, Platyaechmea (Baker) Baker, Podaechmea Mez and Pothuava (Baker) Baker. This infrageneric circumscription is also considered artificial and historically based on few characters (Faria et al. 2004, Sass and Specht 2010).

In Aechmea, potentially useful diagnostic data are still limited and most characters traditionally emphasized in previous taxonomic treatments of the genus (e.g. inflorescence, sepal and floral bract features, pollen grains morphology and petal appendages presence) have often failed to delimit natural groups (Faria et al. 2004, Schulte and Zizka 2008). Thus, an investigation of different characters besides the ordinary external morphology (e.g. anatomical aspects) became essential to provide additional and valuable data to increase knowledge about the systematics of the genus. The function and adaptive value of anatomical features are often extremely useful as they may help to reveal more clearly the homologies of structures for classification purposes and reconstruction of phylogeny (Stuessy 1990). Structural aspects of some vegetative organs, for example, have contributed to the generic/infrageneric delimitation of many groups (Weiner and Liese 1993, Starr and Ford 2001, Alves et al. 2002, Calvente et al. 2008, Oliveira et al. 2008, Cardoso et al. 2009).

The taxonomic and phylogenetic use of anatomical characters, especially leaves', has been helpful in the delimitation of different genera of Bromeliaceae (Robinson 1969, Varadarajan and Gilmartin 1988, Gilmartin et al. 1989, Sajo et al. 1998, Almeida et al. 2009). For Aechmea, foliar anatomical aspects have been investigated in descriptive works (Tomlinson 1969, Smith and Downs 1974, Flores 1975, Braga 1977, Benzing 2000b), using an ecophysiological approach (Scarano et al. 2002), or used as a tool for taxonomic delimitations of the subgenera Lamprococcus (Aoyama and Sajo 2003) and Chevaliera (Sousa et al. 2005) and for species of the genus occurring in São Paulo state, southeast Brazil (Proença and Sajo 2004).

Aechmea subgenus Macrochordion, the focus of this study, is characterized by grouping epiphytes, terrestrials and rupicolous medium-sized species, presenting simple, densely floccose or lanate inflorescences with sessile and polystichous flowers; entire carinate and unarmed floral bracts; unarmed and connate sepals, and well-developed fringed petal appendages (Faria et al. 2010). The species share great morphological similarity, which makes delimitation difficult, especially when some diagnostic characters are poorly preserved or not mentioned on the labels of herbarium specimens (e.g. calyx and corolla color). The subgenus is entirely restricted to the Brazilian Atlantic Forest, except for A. bromeliifolia, which occurs from Central America to Argentina. In a recent taxonomic revision, Faria et al. (2010) recognized five species of Macrochordion: (1) A. alba Mez; (2) A. bromeliifolia Rudge (Baker), including the typical variety and $A$. bromeliifolia var. albobracteata Philcox; (3) A. lamarchei Mez; (4) A. maasii Gouda \& W. Till and (5) A. triangularis L.B.Sm, as well 
as placed five previously recognized taxa into synonymy: (1) A. maculata and (2) A. chlorophylla (both under A. lamarchei); (3) A. pabstii (under A. alba); (4) A. kautskyana (under A. triangularis) and (5) A. bromeliifolia var. angustispica (under $A$. bromeliifolia var. bromeliifolia).

The present study describes the foliar structure of Aechmea subgenus Macrochordion with the aim of providing additional morphological characters to support the systematic boundaries of the species, as well as identifying anatomical adaptations to their respective habitats.

\section{MATERIALS AND METHODS}

Leaves were obtained from cultivated specimens at the Universidade Federal do Rio de Janeiro (adult shoots from individuals collected in the field and maintained in a greenhouse). A voucher for each studied sample was deposited in the RFA herbarium under the following specifications: A. alba, Porto Seguro, Bahia, Faria et al. 139; A. bromeliifolia var. albobracteata, Santo Antônio do Itambé, Minas Gerais, Faria \& Versieux 171; A. bromeliifolia var. bromeliifolia, Arcos, Minas Gerais, Faria 176; A. lamarchei, Santa Teresa, Espírito Santo, Faria et al. 161; A. maasii, Armação de Búzios, Rio de Janeiro, Wendt et al. 443; A. triangularis, Santa Teresa, Espírito Santo, Faria et al. 165.

Samples from the middle region of adult leaf blades were fixed in a solution of formaldehydeacetic acid-alcohol 50\% and then transferred and stored in 50\% alcohol (Johansen 1940). Transverse freehand sections were obtained using a razor blade, bleached with sodium hypochlorite and stained with Astra blue-Safranin (Bukatsch 1972). The histological slides were mounted in 50\% glycerine and observed with an Olympus $\mathrm{CH} 30$ light microscope. For histochemistry, fresh sections were submitted to the following tests: Lugol for starch (Johansen 1940), Sudan IV for lipids (Gerlach 1984) and acidic phloroglucin for lignin (Sass 1951).

\section{RESULTS}

The leaf epidermis of Aechmea subgenus Macrochordion species is organized in a single layer of cells and in transverse section can be almost plane on both surfaces, as in A. lamarchei (Fig. 1A), undulating on the abaxial surface in A. bromeliifolia var. albobracteata (Fig. 1B) and A. triangularis (Fig. 1C) or on both surfaces, as in A. bromeliifolia var. bromeliifolia (Fig. 1D), A. alba (Fig. 1E) and $A$. maasii (Fig. 1F). All epidermal cells have a reduced lumen with very thick and lignified anticlinal and internal periclinal walls (Fig. 2A), including one nearly spherical silica body (Fig. 2F). The external periclinal walls are covered with a thin cuticle, except in A. triangularis, which possesses a dense covering (Fig. 2G). All taxa have peltate trichomes on both surfaces, with the stalk composed of two cells sunk into epidermal depressions (Fig. 2A) and hypostomatic leaves with sunken stomata below the other ordinary epidermal cells (Fig.1A-F, Fig. 2B).

All taxa have an adaxial and abaxial hypodermis. This tissue is more developed adaxially and executes a mechanical function due to cell wall thickening. The mechanical hypodermis is arranged in one or two layers of thickened or slightly thickened cells (Table I). Slightly thickened cells are observed in A. alba (Fig. 2C), A. maasii (Fig. 2D) and $A$. lamarchei (Fig. 2E) and thick-walled cells in A. bromeliifolia var. bromeliifolia (Fig. 2F), A. bromeliifolia var. albobracteata and $A$. triangularis (Fig. 2G). The cells are nearly isodiametric, except in A. triangularis, where the first layer of the adaxial surface presents anticlinally extended hypodermic cells (Fig. 2G). Lignified walls are also observed only in A. triangularis, and the remaining taxa exhibit a non-lignified hypodermis.

All taxa have a water parenchyma formed by cells without chloroplasts and with thin cellulosic walls, located below the adaxial mechanical hypodermis (Fig.1A-F). The number of layers of water parenchyma varies from one to five (Table 
I), being more developed in A. bromeliifolia var. bromeliifolia, A. triangularis and A. bromeliifolia var. albobracteata (Fig. 1B-D). Below the water parenchyma, the chlorenchyma occupies the greater portion of the mesophyll (Fig. 1A-F) and is formed by anticlinally extended cells arranged like a palisade on the adaxial surface of $A$. bromeliifolia var. albobracteata (Fig. 1B, Table I) and on both surfaces of $A$. triangularis (Fig. 1C, Table I). In the remaining taxa, chlorenchymatic cells are slightly extended anticlinally or are almost isodiametric (Fig. 1A, D-F, Table I). Air channels (or air-lacunae in the sense of Tomlinson 1969) alternate with the vascular bundles are also observed in all taxa (Fig. 1A-F). In A. alba, A. lamarchei and A. maasii, the air channels are usually continuous to the substomatal chambers on the abaxial surface and filled with nearly isodiametric cells with short projections (Fig.1A, E, F, Fig.3B, Table I). In A. triangularis, $A$. bromeliifolia var. albobracteata and $A$. bromeliifolia var. bromeliifolia, the air channels are farther from the abaxial surface, with no direct connection to the substomatal chambers, and are filled with stellate cells (Figs. 1B-D, 3A, Table I). Fibrous clusters have a scattered distribution adaxially and abaxially in the chlorenchyma of all examined species (Fig. 1A-F).

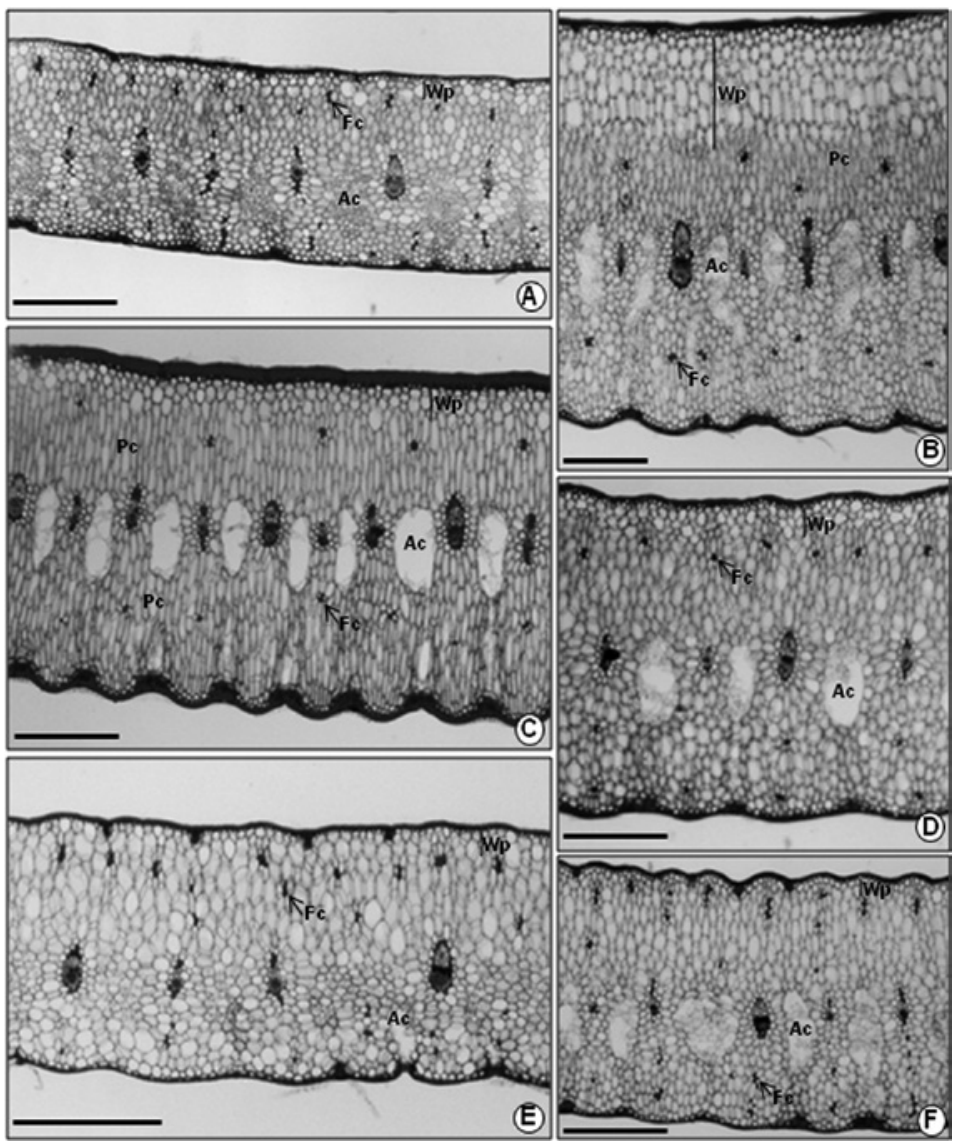

Figure 1 - Transversal sections of leaves of Aechmea subgenus Macrochordion taxa. A-F. Mesophyll overview showing the water parenchyma (Wp), air channels (Ac) and fibrous clusters $(\mathrm{Fc})$ distributed on adaxial and abaxial surfaces. A. A. lamarchei: outline of adaxial and abaxial surfaces almost plane. B. A. bromeliifolia var. albobracteata and C. A. triangularis: outline of abaxial surface undulating and presence of palisade chlorenchyma (Pc). D. A. bromeliifolia var. bromeliifolia, E. A. alba and F A. maasii: outline of adaxial and abaxial surfaces undulating. Bars $=500 \mu \mathrm{m}$. 


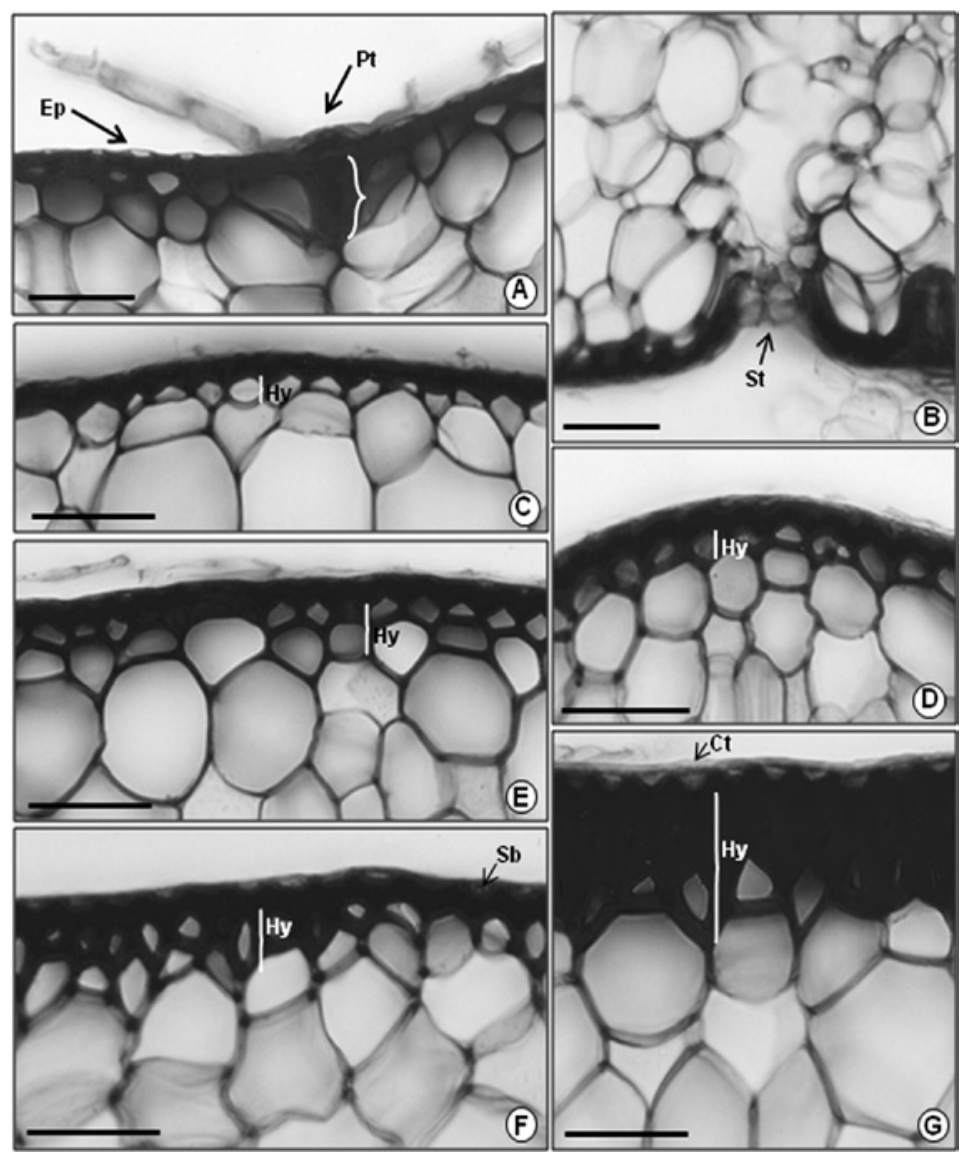

Figure 2 - Details of epidermal cells, trichomes, stomata and mechanical hypodermis. A. Epidermal cell (Ep) with reduced lumen (arrow) and peltate trichome (Pt) on adaxial surface, with the sunk stalk (bracket). B. Stomata (St) sunk in epidermal depressions. C-G. Adaxial mechanical hypodermis (Hy), demonstrating different levels of cell wall thickening. C. A. alba. D. A. maasii. E. A. lamarchei. F. A. bromeliifolia var. bromeliifolia: arrow indicates silica body inclusion $(\mathrm{Sb})$. G. $A$. triangularis: arrow indicates the cuticle $(\mathrm{Ct})$ layer on epidermal cells. Bars $=50 \mu \mathrm{m}$.

In all taxa we observed a single series of collateral vascular bundles arranged in the central portion of the mesophyll (Fig. 1A-F), along with slender commissural bundles (Fig. 3G). The larger vascular bundles are surrounded by slightly thickened and lignified cells (also between the xylem and phloem) and covered by a cap of fibers on the xylem and phloem poles (Fig. 3C, E). This cap of fibers can be totally lignified in A. alba, A. lamarchei and $A$. maasii or incompletely lignified in A. bromeliifolia var. bromeliifolia, A. bromeliifolia var. albobracteata and $A$. triangularis (Table I). The slightly thickened and lignified cells surrounding the smaller vascular bundles do not appear between the xylem and phloem and the cap of fibers can extend to both poles (Fig. 3D) or not (Fig. 3F). In association with the lignified cells and the cap of fibers, we observe a sheath of parenchymatic cells contained starch grains (Fig. 1A-F; 3C-F), smaller than the remaining chlorenchymatic cells of the mesophyll.

\section{DISCUSSION}

The anatomical foliar features of Aechmea subgenus Macrochordion are in accordance with the general patterns observed for Bromeliaceae (Tomlinson 1969, Smith and Downs 1974, 

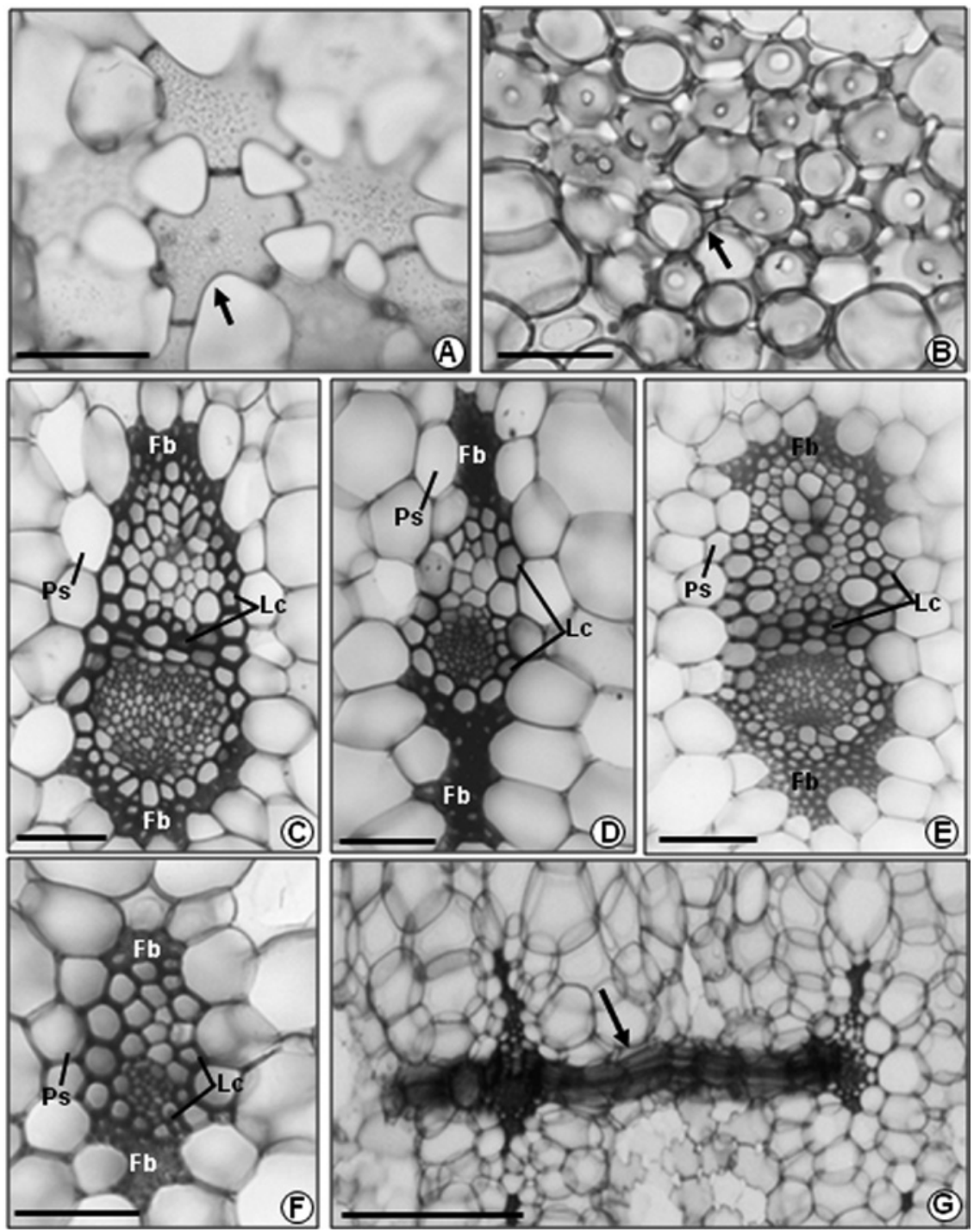

Figure 3 - Detail of the air channels and vascular bundles. A. A. bromeliifolia var. bromeliifolia: stellate cells (arrow). B. A. lamarchei: isodiametric cells with short projections (arrow). C, D. A. lamarchei: larger and smaller vascular bundles, respectively, surrounded by slightly thickened and lignified cells (Lc), unextended and extended cap of fibers ( $\mathrm{Fb}$ ) and a parenchymatic sheath (Ps). E. A. bromeliifolia var. albobracteata and F. A. bromeliifolia var. bromelifoliia: larger and smaller vascular bundles, respectively, surrounded by slightly thickened and lignified cells $(\mathrm{Lc})$, cap of fibers $(\mathrm{Fb})$ and a parenchymatic sheath (Ps). G. A. maasii: detail of commissural bundle (arrow). Bars A-F. $=50 \mu \mathrm{m}$. G. $=200 \mu \mathrm{m}$.

Benzing 2000b). The parenchymatic sheath and fibers involving the vascular bundles are treated as the endodermis and the pericycle, respectively, following the nomenclature of Van Fleet (1961). P.B. Pita (unpublished data), Sajo et al. (1998), Arruda and Costa (2003) and Scatena and Segecin (2005) have also described these structures in other bromeliad species. Although Smith and Downs (1974) suggested that a palisade chlorenchyma is not a common character in the Bromeliaceae, Proença and Sajo (2004) reported the presence of this tissue in an exemplar of $A$. bromeliifolia from São Paulo state, southeastern Brazil. The authors, however, did not specify whether the specimen analyzed 
TABLE I

Leaf anatomy characters observed for Aechmea subgenus Macrochordion with taxonomic relevance in the delimitation of groups of species.

\begin{tabular}{|c|c|c|c|c|c|c|}
\hline \multirow[b]{2}{*}{ CHARACTERS } & \multicolumn{6}{|c|}{ TAXA } \\
\hline & 1 & 2 & 3 & 4 & 5 & 6 \\
\hline Hypodermic cells walls slightly thickened & + & - & - & + & + & - \\
\hline Hypodermic cells walls thickened & - & + & + & - & - & + \\
\hline Water parenchyma with 1-2 layers & + & - & - & + & + & - \\
\hline Water parenchyma with 3-5 layers & - & + & + & - & - & + \\
\hline Chlorenchymatic cells anticlinally extended & - & - & + & - & - & + \\
\hline $\begin{array}{l}\text { Chlorenchymatic cells slightly extended or } \\
\text { almost isodiametric }\end{array}$ & + & + & - & + & + & - \\
\hline $\begin{array}{l}\text { Air channels connected to the substomatal } \\
\text { chambers }\end{array}$ & + & - & - & + & + & - \\
\hline $\begin{array}{l}\text { Air channels not connected to the substomatal } \\
\text { chambers }\end{array}$ & - & + & + & - & - & + \\
\hline $\begin{array}{l}\text { Isodiametric cells with short projections } \\
\text { interrupting the air channels }\end{array}$ & + & - & - & + & + & - \\
\hline Stellate cells interrupting the air channels & - & + & + & - & - & + \\
\hline $\begin{array}{l}\text { Vascular bundles recovered by fibers totally } \\
\text { lignified }\end{array}$ & + & - & - & + & + & - \\
\hline $\begin{array}{l}\text { Vascular bundles recovered by fibers } \\
\text { incompletely lignified }\end{array}$ & - & + & + & - & - & + \\
\hline
\end{tabular}

1: A. alba; 2: A. bromeliifolia var. bromeliifolia; 3: A. bromeliifolia var. albobracteata;

4: A. lamarchei; 5: A. maasii; 6: A. triangularis.

+ : presence; -: absence.

belonged to the typical variety or to the variety albobracteata. Both varieties of $A$. bromeliifolia occur in São Paulo state (Faria et al. 2010), and in this study, we observed anticlinally extended cells arranged like a palisade in var. albobracteata.

The species analyzed show several xeromorphic characters commonly reported for Bromeliaceae (e.g. epidermal cells with lignified thick walls and silica body inclusions, mechanical hypodermis, water parenchyma, sunken stomata and lignified fibers in the mesophyll). Silica bodies have been associated with resistance against herbivory due to their inedibility (MacNaughton et al. 1985, Prychid et al. 2004), but are also important for refracting excess of light, helping individuals to establish in sun-exposed environments (Krauss 1949). These inclusions are also commonly found in other monocots families within Poales, suggesting that this is a plesiomorphic character for the order (Pereira et al. 2011).

According to Tomlinson (1969), sunken stomata below the remaining epidermal cells help to prevent dehydration by transpiration. Several plant families from arid zones, particularly succulents, have stomata deeply sunken in depressions in the epidermis (crypts), such as Agavaceae (Fahn and Cutler 1992) and Cactaceae (Calvente et al. 2008). However, this trait is not restricted among plants exposed to drought 
(Cutler et al. 2007), and recent studies indicate that it is unlikely that the primary function of crypts is to reduce transpiration (Roth-Nebelsick et al. 2009). Some species of Aechmea subgenus Macrochordion (e.g. A. bromeliifolia) can occupy both xeric and mesic habitats (Faria et al. 2010). Previous studies also indicate the occurrence of sunken stomata in other Aechmea species from mesic environments (Proença and Sajo 2004, Sousa et al. 2005) suggesting that the presence of this character may be not a significant adaptation to environmental conditions of low water availability. As discussed by Proença and Sajo (2004), although many xeromorphic characters found in the Bromeliaceae allow the exploration of extreme environments, they can represent ancestral adaptations selected during the diversification of the family and should not be interpreted only as traits related to a particular environment where they currently live.

Besides the position below the other ordinary epidermal cells, the stomata of all Macrochordion taxa are restricted to the abaxial surface. Hypostomatism is a common condition for Bromeliaceae (Tomlinson 1969) and was also reported for other Aechmea species from subgenera Lamprococcus (Aoyama and Sajo 2003), Platyaechmea, Pothuava, Ortgiesia (Proença and Sajo 2004) and Chevaliera (Sousa et al. 2005). According to Fahn and Cutler (1992) stomata restricted to the abaxial surface are more common in plants from humid environments. Other authors have suggested that hypostomatic leaves may be a strategy to minimize water loss by convection currents or breezes that could remove water vapor from the leaf surface (Nobel 1999). Scatena and Segecin (2005) investigated the foliar anatomy of some Tillandsia (Tillandsioideae) in which xeromorphic traits are predominant, and argued that the presence of hypostomatic leaves in these species, may be more of a plesiomorphic condition retained than a response to environmental selection.

The hypodermis, along with the thick and lignified epidermal cells and the vascular and extravascular fiber bundles develop a mechanical function of strengthing the foliar structure. These tissues can also protect against hydric and temperature stress by reducing water evaporation from internal tissues and preventing mesophyll collapse in unfavorable abiotic conditions (Krauss 1949, Brighigna et al. 1984, Fahn and Cutler 1992). Besides avoiding water loss, the water parenchyma also protects the chlorenchymatic cells against excessive luminosity (Brighigna et al. 1984). The thick-walled hypodermic cells and greater amount of water parenchyma observed in A. bromeliifolia var. bromeliifolia, A. bromeliifolia var. albobracteata and A. triangularis may be adaptations to the particular environmental conditions and habits of these species. The main habitats occupied by $A$. bromeliifolia var. bromeliifolia and A. bromeliifolia var. albobracteata are dry and/or sun-exposed (Faria et al. 2010), such as the rocky grasslands (campos rupestres), caatingas and savannas (cerrados). Although A. triangularis is restricted to humid habitats of the Atlantic Forest (Faria et al. 2010), it grows only as epiphyte, and mostly in the higher strata of trees. Besides the water stressful condition created by the epiphytic life form, this species receives intense levels of luminosity. The remaining taxa (A. alba, A. maasii and A. lamarchei) grow as terrestrials or epiphytes, preferentially in humid and/or shaded habitats of dense ombrophile and semideciduous forests, shrubby and wooded sandy coastal plains (restingas) and tableland forests (Faria et al. 2010). Consequently, their foliar structures have a less well-developed water parenchyma and the cells of the mechanical hypodermis have thinner walls. Aechmea alba, A. lamarchei and A. maasii are also characterized by the air channels contiguous to the substomatal chambers, and the same character was reported for other Aechmea species from mesic habitats studied by Aoyama and Sajo (2003), Proença and Sajo (2004) and Sousa et al. (2005). Tomlinson (1969) argued that the air channels facilitate ventilation in species from mesic environments and are usually connected to the substomatal chambers 
in leaves of mesophytic bromeliads. In the subgenus Macrochordion, the occurrence of this character may also suggest an adaptation of the species to their respective habitats.

As observed by Versieux et al. (2010) for closely related species of the genus Alcantarea (Tillandsioideae), most of the anatomical features examined in this study are also very homogeneous within the Aechmea subgenus Macrochordion. However, some of the characters that were investigated are useful to characterize particular taxa, as well as circumscribing groups of species, strengthening the relationships indicated by their external morphology. Aechmea triangularis exhibits unique anatomical traits, such as a thick cuticle layer on the epidermal surface, anticlinally extended and sclerified hypodermic cells, and a palisade chlorenchyma on both faces of the leaf. Some aspects of the vegetative and reproductive external morphology also distinguish A. triangularis from other Macrochordion species, such as leaves with caudate and recurvate apices and a blue corolla (Faria et al. 2010). The leaf structure of $A$. triangularis is more similar to the same observed for both varieties of $A$. bromeliifolia due to the presence of a well-developed water parenchyma, hypodermic cells with thick walls, air channels not connected to the substomatal chambers and filled with stellate cells, and vascular bundles covered by a cap of incompletely lignified fibers. The close relationship among these taxa is also reflected by some aspects of their external morphology, such as the presence of leaf spines longer than $3 \mathrm{~cm}$, emarginate, symmetric to slightly asymmetric and half connate sepals, and spatulate petals with emarginated apices (Faria et al. 2010). Similarly, A. alba, A. lamarchei and A. maasii have leaf spines up to $3 \mathrm{~mm}$ long, obtuse and distinctly asymmetric sepals and lingulate petals with obtuse apices (Faria et al. 2010). These species also share some anatomical features not observed in A. bromeliifolia and A. triangularis, such as a less developed water parenchyma, hypodermic cells with thinner walls, air channels filled with nearly isodiametric cells with short projections and connected to the substomatal chambers, and vascular bundles covered by a totally lignified cap of fibers. Variations in the shape of the cells interrupting the air channels were also reported by Aoyama and Sajo (2003) and Sousa et al. (2005), and showed to be useful in the delimitation of species within Aechmea subgenera Lamprococcus and Chevaliera.

This study contributed to a better understanding of some anatomical traits responsible for the adaptation of the Macrochordion species to their respective habitats and habits, as well as revealed some useful taxonomical characters to characterize particular species and to delimit groups of species. We also contributed with potential data to be explored in future phylogenetic studies within the subgenus and between Aechmea and other related Bromelioideae genera.

\section{ACKNOWLEDGMENTS}

We thank the Coordenação de Aperfeiçoamento de Pessoal de Nível Superior (CAPES) for the scholarship to Ana Paula G. de Faria and the Conselho Nacional de Desenvolvimento Científico e Tecnológico (CNPq) for a productivity grant to Tânia Wendt. This paper is part of a $\mathrm{PhD}$ thesis undertaken at the Graduate Program in Botany of the Universidade Federal do Rio de Janeiro by the first author.

\section{RESUMO}

A anatomia foliar de espécies de Aechmea subgênero Macrochordion foi analisada visando obter caracteres úteis para sua delimitação taxonômica e identificar adaptações anatômicas aos seus respectivos habitats e hábitos. Todas as folhas são hipoestomáticas e apresentam: tricomas peltados nas duas superfícies; estômatos inseridos em depressões da epiderme; células epidérmicas pequenas, com paredes espessadas e inclusões de corpos de sílica; 
hipoderme mecânica; parênquima aquífero; clorênquima com feixes de fibras e canais de aeração; feixes vasculares envolvidos por bainha parenquimática e calotas de fibras. Os resultados são avaliados dentro de um contexto adaptativo e taxonômico. Variações no espessamento da hipoderme, na quantidade de parênquima aquífero, na posição dos canais de aeração e na forma das células que preenchem os canais de aeração mostraram-se úteis para separar grupos de espécies, corroborando relações de similaridade apontadas pela morfologia externa.

Palavras-chave: Aechmea, Bromeliaceae, anatomia foliar, Macrochordion.

\section{REFERENCES}

Almeida VR, Costa AF, Mantovani A, GONÇALVES-ESTEVES V, ARRUdA RCO AND ForZZA RC. 2009. Morphological phylogenetics of Quesnelia (Bromeliaceae, Bromelioideae). Syst Bot 34: 660-672.

ALVES MV, EsTElitA MEM, WANDERLEY MGL AND THOMAS WW. 2002. Aplicações taxonômicas da anatomia foliar das espécies brasileiras de Hypolytrum Rich. (Cyperaceae). Rev Bras Bot 25: 1-9.

AOYAMA EM AND SAJO MG. 2003. Estrutura foliar de Aechmea Ruiz \& Pav. subgênero Lamprococcus (Beer) Baker e espécies relacionadas. Rev Bras Bot 26: 461-473.

APG - ANGiosperm Phylogeny Group. 2009. An update of the Angiosperm Phylogeny Group classification for the orders and families of flowering plants: APG III. Bot J Lin Soc 161: 105-121.

ARrudA RC AND CostA AF. 2003. Foliar anatomy of five Vriesea sect. Xiphion (Bromeliaceae) species. Selbyana 24: 180-189.

BENZING DH. 1976. Bromeliad trichomes: structure, function, and ecological significance. Selbyana 1: 330-348.

BENZING DH. 2000a. Introduction. In: Benzing DH (Ed), Bromeliaceae: profile of an adaptive radiation. Cambridge: Cambridge University Press, p. 3-15.

BENZING DH. 2000b. Vegetative structure. In: Benzing DH (Ed), Bromeliaceae: profile of an adaptive radiation. Cambridge: Cambridge University Press, p. 19-77.

Braga MMN. 1977. Anatomia foliar de Bromeliaceae da Campina. Acta Amaz 7: 1-74.

BRIGHIGNA L, FIORDI AC AND PALANDRI MR. 1984. Structural characteristics of mesophyll in some Tillandsia species. Phytomorphology 34: 191-200.

BUKATSCH F. 1972. Bemerkungen zur Doppelfärbung AstrablauSafranin. Mikrokosmos 61: 255.

CAlvente AM, ANDREATA RHP AND VIEIRA RC. 2008. Stem anatomy of Rhipsalis (Cactaceae) and its relevance for taxonomy. P1 Syst Evol 276: 1-7.
Cardoso CMV, Proença SL and Sajo MG. 2009. Foliar anatomy of the subfamily Myrtoideae (Myrtaceae). Aust J Bot 57: 148-161.

Cutler DF, Botha T And Stevenson DW. 2007. Plant Anatomy: an applied approach. Malden: Blackwell Publishing, $302 \mathrm{p}$.

FAHN A AND CUTLER DF. 1992. Xerophytes. Encyclopedia of Plant Anatomy. Band 13, Teil 3. Berlin: Gebrüder Borntraeger, $175 \mathrm{p}$.

FARIA APG, WENDT T AND BROWN GK. 2004. Cladistic relationships of Aechmea (Bromeliaceae: Bromelioideae) and allied genera. Ann Missouri Bot Gard 91: 303-319.

FARIA APG, WENDT T AND BROWN GK. 2010. A revision of Aechmea subgenus Macrochordion (Bromeliaceae) based on phenetic analyses of morphological variation. Bot $\mathrm{J}$ Linn Soc 162: 1-27.

FLORES EM. 1975. Algunos aspectos de anatomia foliar comparada de dos especies de Bromeliaceae (Aechmea mexicana Baker y Hechtia glomerata Zucc.). Rev Biol Trop 23: 29-52.

GERLACH D. 1984. Botanische Mikrotechnik: eine einführung. Stuttgart: Georg Thieme Verlag, 298 p.

GILMARTIN AJ, BROWN GK, VARADARAJAN GS AND NeIGHBOURS M. 1989. Status of Glomeropitcairnia within evolutionary history of Bromeliaceae. Syst Bot 14: 339-348.

Givnish TJ, Millam KC, BerRy PE and Sytsma KJ. 2007. Phylogeny, adaptive radiation, and historical biogeography of Bromeliaceae inferred from ndhF sequence data. Aliso 23: $3-26$

JOHANSEN D. 1940. Plant microtechnique. New York: McGrawHill, $523 \mathrm{p}$.

KRAUSS BH. 1949. Anatomy of the vegetative organs of the pineapple, Ananas comosus (L.) Merr. II. The leaf. Bot Gaz 110: 333-404.

LUTHER HE. 2008. An alphabetical list of bromeliad binomials, $11^{\text {th }}$ ed., Orlando: BSI, $114 \mathrm{p}$.

MaCnAUGHTON SJ, TARRANTS JL, MACNAUGHTON MM AND DAVIS RH. 1985. Silica as a defense against herbivory and a growth promoter in African grasses. Ecology 66: 528-535.

NoBEL PS. 1999. Physicochemical and environmental plant physiology, $2^{\text {nd }}$ ed., San Diego: Academic Press, 540 p.

OLIVEIRA RJ, LONGHI-WAGNER HM AND LEITE KRB. 2008. A contribuição da anatomia foliar para a taxonomia de Raddia Bertol. (Poaceae: Bambusoideae). Acta Bot Bras 22: 1-19.

Pereira TAR, Oliveira TSO, Silva LC AND AZEVEdo AA. 2011. Comparative leaf anatomy of four species of Bromelioideae (Bromeliaceae) occurring in the Atlantic Forest, Brazil. Botany 89: 243-253.

Proença SL AND SAJo MG. 2004. Estrutura foliar de espécies de Aechmea Ruiz \& Pav. (Bromeliaceae) do Estado de São Paulo. Acta Bot Bras 18: 319-331.

PRYCHID CJ, RudAll PJ AND GREGORY M. 2004. Systematics and biology of silica bodies in monocotyledons. Bot Rev 69: $377-440$ 
RoBINSON H. 1969. A monograph on foliar anatomy of the genera Connelia, Cottendorfia, and Navia (Bromeliaceae). Smithsonian Contrib Bot 2: 1-41.

Roth-Nebelsick A, Hassiotou F And VeneKLaAs EJ. 2009. Stomatal crypts have small effects on transpiration: a numerical model analysis. Plant Physiol 151: 2018-2027.

SAJO MG, MACHAdO SR AND CARMELlO-GUERREIRO SM. 1998. Aspectos estruturais de folha de bromélia e suas implicações no agrupamento de espécies. In: PEREIRA MV (Ed), Bromélias da Mata Atlântica: Canistropsis, Rio de Janeiro: Salamandra, p. 102-111.

SASS JE. 1951. Botanical microtechnique, $2^{\text {nd }}$ ed., Iowa: Iowa State College Press, 228 p.

SAss C AND SPECHT CS. 2010. Phylogenetic estimation of the core Bromelioids with an emphasis on the genus Aechmea (Bromeliaceae). Mol Phylogenet Evol 55: 550-571.

SCARANO FR, DUARTE HM, RôçAS G, BARRETO SMB, AMADO EF, REINERT F, WENDT T, MANTOVANI A, LIMA HRP AND BARRos CFB. 2002. Acclimation or stress symptom? An integrated study of intraspecific variation in the clonal plant Aechmea bromeliifolia, a widespread CAM tankbromeliad. Bot J Linn Soc 140: 391-401.

SCATENA VL AND SEgEcin S. 2005. Anatomia foliar de Tillandsia L. (Bromeliaceae) dos Campos Gerais, Paraná, Brasil. Rev Bras Bot 28: 635-649.

SCHULTE K AND ZIZKA G. 2008. Multi locus plastid phylogeny of Bromelioideae (Bromeliaceae) and the taxonomic utility of petal appendages and pollen characters. Candollea 63: 209-255.

SMITH LB. 1934. Geographical evidence on the lines of evolution in the Bromeliaceae. Bot Jahrb 66: 446-465.

SMIth LB AND Downs RJ. 1974. Pitcairnioideae (Bromeliaceae). In: WURDACK JJ (Ed), F1 Neotropica Mon 14, part 1, New York: Hafner Press, p. 1-658.
SMITH LB AND Downs RJ. 1977. Tillandsioideae (Bromeliaceae). In: ROGERSON CT (Ed), Fl Neotropica Mon 14, part 2. New York: Hafner Press, p. 663-1492.

SMITH LB AND Downs RJ. 1979. Bromelioideae (Bromeliaceae). In: ROGERSON CT (Ed), Fl Neotropica Mon 14, part 3, New York: Hafner Press, p. 1493-2141.

SOUSA GM, EsTELITA MEM AND WANDERLEY MGL. 2005. Anatomia foliar de espécies brasileiras de Aechmea subg. Chevaliera (Gaudich. ex Beer) Baker, BromelioideaeBromeliaceae. Rev Bras Bot 28: 603-613.

STARR JR AND FORD BA. 2001. The taxonomic and phylogenetic utility of vegetative anatomy and fruit epidermal silica bodies in Carex section Phyllostachys (Cyperaceae). Can J Bot 79: 362-379.

STUESSY TF. 1990. Plant taxonomy: the systematic evaluation of comparative data. New York: Columbia University Press, $514 \mathrm{p}$.

Tomlinson PB. 1969. Commelinales-Zingiberales. In: METCALF CR (Ed), Anatomy of the Monocotyledons, vol. 3, Oxford: Oxford University Press, p. 192-294.

VAN FLEET DS. 1961. Histochemistry and function of the endodermis. Bot Rev 27: 165-220.

VARADARAJAN GS AND GILMARTIN AJ. 1988. Taxonomic realignments within the subfamily Pitcairnioideae (Bromeliaceae). Syst Bot 13: 294-299.

VersieuX LM, Elbl PM, WANDERLEy MGL AND MenEZes NL. 2010. Alcantarea (Bromeliaceae) leaf anatomical characterization and its systematic implications. Nord J Bot 28: 385-397.

WEINER G AND LIESE W. 1993. Generic identification key to rattan palms based on stem anatomy characters. IAWA J 14: 55-61. 